\title{
Early Marriage and Its Relationship with Child Development
}

\author{
Ayling Sanjaya ${ }^{1}$, Moersintowarti B. Narendra ${ }^{2}$, Irwanto ${ }^{2}$, Ahmad Suryawan ${ }^{2}$, Mira Irmawati ${ }^{2}$, \\ Ferry Efendi ${ }^{3}$ \\ ${ }^{1}$ Faculty of Medicine, Wijaya Kusuma University, Surabaya; ${ }^{2}$ Faculty of Medicine, ${ }^{3}$ Faculty of Nursing, \\ Universitas Airlangga, Surabaya
}

\begin{abstract}
Background: Early marriage is still a problem in the world, especially in developing countries including Indonesia. The problem of early marriage in Indonesia takes place both in urban and rural areas with diverse population economic status.
\end{abstract}

Objective: This study aimed to analyze the relationship between early marriage and child development.

Method: This study used a cross-sectional approach design. The independent variable in this research was early marriage, while the dependent variable in this research was the development of the child. The population in this research was all toddlers residing in a region of Situbondo Regency.

The total sample was 67 respondents who got married when 18 years old or younger. Data were collected through questionnaires and measurements of height, weight, and nutritional status and progress was assessed through interviews and the Denver Development Screening Test (DDST) II. Data were analyzed with the Pearson correlation test with $\mathrm{p}<0.05$.

Results: Early marriage has no association with child growth but it has a relationship with child development. In this study there was a significant relationship found between early marriage of the mother and child development $(\mathrm{p}<0.001)$. The risk of a child experiencing developmental disorders when the mother marries early was found to be 62 times compared to mothers who married at an early age.

Conclusion: Early marriage does not cause growth disorders of children, but early marriage has the potential to cause delay in child development. Early childbirth does not cause growth disorders of children. Women who experienced early childbirth might cause general developmental delays in children.

Keyword: early marriage childhood, child development, child growth.

\section{INTRODUCTION}

Early marriage remains a problem especially in developing countries like Indonesia. ${ }^{1-3}$ The latest data released in the year 2017 show that the prevalence of early marriage is high. ${ }^{4}$ Previous data showed that Indonesia ranks second as the country with the highest rates of child marriage among ASEAN Countries. ${ }^{5}$ Average births to adolescents aged 15-19 years in Indonesia increased from 35 per 1,000 live births in 2007 to 45 per 1,000 in

\footnotetext{
Corresponding Author:

Ferry Efendi

Faculty of Nursing, Universitas Airlangga, Surabaya

Email: ferry-e@fkp.unair.ac.id
}

2012. ${ }^{6}$ Although many countries have decided on a legal minimum age of marriage of 18 , Indonesia is struggling to change its policy. ${ }^{4}$ The problem of early marriage is a classic problem faced in Indonesia, considering the marriage rule has been legalized since $1974 .{ }^{7}$ The increasing number of adolescents who give birth might be correlated with the increased phenomenon of early marriage in some areas. ${ }^{5}$

Physical and psychological development of immature babies at an early age causes health and social problems. ${ }^{8}$ Some of the problems in child marriage include factors that encourage the marriage of children, their effect on education, the occurrence of domestic violence, the impact on reproductive health, childbirth and child psychological health, and legal views related to child marriage. ${ }^{9}$ Indonesia has been gradually improving 
its maternal health services across the nation. ${ }^{10-13}$ However, some of the targets are behind track in the national development such as maternal mortality, ${ }^{6}$ child mortality and early marriage prevalence. ${ }^{14,15}$

Research related to the relationship between early marriage and child growth and development is still very limited and more research on growth and social aspects is needed. ${ }^{16}$ lower educated people, and rural residents. Females, more educated people and rural $\backslash n$ residents enter first marriage sooner following intercourse initiation than their corresponding $\backslash$ ncounterparts. People who engage with premarital sexual intercourse enter first marriage later Inthan their counterparts. The long time span to first marriage following premarital sexual $\backslash$ nintercourse initiation needs to be addressed and considered in the current policy which is to $\backslash$ naccommodate comprehensive sexual reproductive health (SRH The purpose of this study was to analyze the relationship between early marriage and child growth and development.

\section{METHOD}

This study design was cross-sectional with children all under 5 years old born to an early married couple when less than or equal to 18 years of age. The inclusion criteria of this study were adolescent marriages having children under 5 years old. The independent variable in this research was early marriage, while the dependent variable was the growth and development of the child. Growth in this study was measured by nutritional status as a $\mathrm{WH} / \mathrm{BB} \mathrm{z}$-score plot.

Parameters assessed in regard to child development were collected using DDST II. Selection of the sample was undertaken by total random sampling in married couples who had children under 5 years old. Data were collected from couples with children in one of the community health centers in Situbondo Regency, with permission from the local authority. This study has passed the ethical clearance of the Faculty of Medicine, Universitas Airlangga, Surabaya. The data obtained are tabulated and presented in the form of descriptive statistics and Pearson correlation statistics test at $\mathrm{p}<0.05$.

\section{RESULTS}

Half of the respondents were male numbering 37 $(55.2 \%)$ and $30(44.8 \%)$ were female with an average age of $28.21(\mathrm{SD}=16.50)$ months. The maternal age average in this study was $26.48(\mathrm{SD}=6.12)$ years and the marriage age of mothers had a mean value of 18.51 $(\mathrm{SD}=5.17)$ years.
Table 1: Demographic characteristics of the respondents $(n=67)$

\begin{tabular}{|c|c|c|c|}
\hline Characteristics & $\mathbf{n}$ & $\%$ & SD \\
\hline \multicolumn{4}{|l|}{ Gender of Child } \\
\hline Male & 37 & 55.2 & \\
\hline Female & 30 & 44.8 & \\
\hline $\begin{array}{l}\text { Child's Age (month); mean } \\
\text { (SD) }\end{array}$ & 28.21 & & 16.50 \\
\hline $\begin{array}{l}\text { Mother's Age (year); mean } \\
\text { (SD) }\end{array}$ & 26.48 & & 6.12 \\
\hline $\begin{array}{l}\text { Age of married mother } \\
\text { (year); mean (SD) }\end{array}$ & 18.51 & & 5.17 \\
\hline $\begin{array}{l}\text { Age of mother (year); mean } \\
\text { (SD) }\end{array}$ & 21.58 & & 5.04 \\
\hline
\end{tabular}

\section{Mother's education}

\begin{tabular}{|c|c|c|c|}
\hline $\begin{array}{c}\text { Didn't complete Elementary } \\
\text { School }\end{array}$ & 1 & 1.5 & \\
\hline $\begin{array}{c}\text { Completed Elementary } \\
\text { School }\end{array}$ & 37 & 55.2 & \\
\hline $\begin{array}{c}\text { Graduated from junior high } \\
\text { school }\end{array}$ & 7 & 10.4 & 31.3 \\
\hline $\begin{array}{c}\text { Graduated from senior high } \\
\text { school }\end{array}$ & 21 & 31.55 & 6.67 \\
\hline $\begin{array}{c}\text { Father's age (year); mean } \\
\text { (SD) }\end{array}$ & 23.21 & 5.50 \\
\hline $\begin{array}{c}\text { Age of married father (year); } \\
\text { mean (SD) }\end{array}$ & & \\
\hline Father's Edion & & & \\
\hline
\end{tabular}

\section{Father's Education}

\begin{tabular}{|c|c|c|c|}
\hline $\begin{array}{c}\text { Didn't complete Elementary } \\
\text { School }\end{array}$ & 2 & 3.0 & \\
\hline $\begin{array}{c}\text { Completed Elementary } \\
\text { School }\end{array}$ & 37 & 55.2 & \\
\hline $\begin{array}{c}\text { Graduated from junior high } \\
\text { school }\end{array}$ & 7 & 10.4 & \\
\hline $\begin{array}{c}\text { Graduated from senior high } \\
\text { school }\end{array}$ & 21 & 31.3 & \\
\hline
\end{tabular}

Father's Job

\begin{tabular}{|c|c|c|c|}
\hline Labor & 6 & 9.0 & \\
\hline Farmer & 29 & 43.3 & \\
\hline Private & 18 & 26.9 & \\
\hline Employees & 14 & 20.9 & \\
\hline
\end{tabular}

The results of bivariate analysis of $\leq 18$ years and $>18$ years among adolescent mother listed in Table 2 below. 
Table 2: The relationship between maternal marriage age and the characteristics of the subjects

\begin{tabular}{|c|c|c|c|}
\hline & $\leq 18$ years & $>18$ years & $\mathbf{p}$ \\
\hline \multicolumn{4}{|l|}{ Gender } \\
\hline Male & $24(64.9 \%)$ & $13(35.1 \%)$ & \multirow{2}{*}{0.682} \\
\hline Female & $18(60.0 \%)$ & $12(40.0 \%)$ & \\
\hline \multicolumn{4}{|c|}{ Daily care taker } \\
\hline Mother & $31(62.0 \%)$ & $19(38.0 \%)$ & \multirow[b]{2}{*}{0.842} \\
\hline $\begin{array}{l}\text { Family } \\
\text { member }\end{array}$ & $11(64.7 \%)$ & $6(35.3 \%)$ & \\
\hline
\end{tabular}

\section{Mother's education}

\begin{tabular}{|c|c|c|c|}
\hline $\begin{array}{c}\text { Didn't } \\
\text { complete } \\
\text { Elementary } \\
\text { school }\end{array}$ & $1(100 \%)$ & 0 & \multirow{4}{*}{$<0.001$} \\
\hline $\begin{array}{c}\text { Completed } \\
\text { Elementary } \\
\text { school }\end{array}$ & $32(86.5 \%)$ & $5(13.5 \%)$ & \\
\hline $\begin{array}{l}\text { Graduated } \\
\text { from junior } \\
\text { high school }\end{array}$ & $8(72.7 \%)$ & $3(27.3 \%)$ & \\
\hline $\begin{array}{l}\text { Graduated } \\
\text { from senior } \\
\text { high school }\end{array}$ & $1(5.6 \%)$ & $17(94.4 \%)$ & \\
\hline \multicolumn{4}{|l|}{ Mother's Job } \\
\hline Housewife & $42(62.7 \%)$ & $25(37.3 \%)$ & 0.758 \\
\hline
\end{tabular}

\section{Father's Education}

\begin{tabular}{|c|c|c|c|}
\hline $\begin{array}{c}\text { Didn't } \\
\text { complete } \\
\text { Elementary } \\
\text { school }\end{array}$ & $1(50 \%)$ & $1(50 \%)$ & \multirow{4}{*}{$<0.001$} \\
\hline $\begin{array}{c}\text { Completed } \\
\text { Elementary } \\
\text { school }\end{array}$ & $33(89.2 \%)$ & $4(10.8 \%)$ & \\
\hline $\begin{array}{l}\text { Graduated } \\
\text { from junior } \\
\text { high school }\end{array}$ & $5(71.4 \%)$ & $2(28.6 \%)$ & \\
\hline $\begin{array}{l}\text { Graduated } \\
\text { from junior } \\
\text { high school }\end{array}$ & $3(14.3 \%)$ & $18(85.7 \%)$ & \\
\hline \multicolumn{4}{|l|}{ Father's Job } \\
\hline Laborer & $6(100.0 \%)$ & 0 & \multirow{4}{*}{$<0.001$} \\
\hline Farmer & $25(86.2 \%)$ & $4(13.8 \%)$ & \\
\hline Private & $8(44.4 \%)$ & $10(55.6 \%)$ & \\
\hline Employees & $3(21.4 \%)$ & $11(78.6 \%)$ & \\
\hline
\end{tabular}

This study found that age at marriage and nutritional status is not significantly related to the age of the mother (Table 3). In the same vein, age at birth is not significantly related to child's nutritional status.
Table 3: The relationship between maternal marriage age and maternal birth age with child's nutritional status

\begin{tabular}{|c|c|c|c|}
\hline \multicolumn{4}{|c|}{ Age of married mother } \\
\hline & $\leq 18$ years & $>18$ years & $\mathbf{p}$ \\
\hline \multicolumn{4}{|c|}{ Nutritional status of children } \\
\hline Normal & $27(56.3 \%)$ & $21(43.8 \%)$ & \multirow{5}{*}{0.393} \\
\hline Skinny & $1(100.0 \%)$ & 0 & \\
\hline Risk of obese & $7(70.0 \%)$ & $3(30.0 \%)$ & \\
\hline Fat & $3(100.0 \%)$ & 0 & \\
\hline Very fat & $4(80.0 \%)$ & $1(20.0 \%)$ & \\
\hline \multicolumn{4}{|c|}{ Age of delivery mother } \\
\hline \multicolumn{4}{|c|}{ Nutritional status of children } \\
\hline Normal & $12(25.0 \%)$ & $36(75.0 \%)$ & \multirow{5}{*}{0.279} \\
\hline Skinny & $1(100.0 \%)$ & 0 & \\
\hline Risk of obese & $3(30.0 \%)$ & $7(30.0 \%)$ & \\
\hline Fat & $2(66.7 \%)$ & $1(33.3 \%)$ & \\
\hline Very fat & $2(40.0 \%)$ & $3(60.0 \%)$ & \\
\hline
\end{tabular}

In Table 4 it can be seen that the developmental status of the child at the marriage age of the mother $\leq$ 18 years at most is the delay of 30 children $(71.4 \%)$ and the normal development of 12 children (28.6\%). Mothers who married at the age of 18 years or more had all children with normal development, that is as many as 2 children (100.0\%). Analysis of the relationship between maternal marriage age and child development status was found to have a significant relationship with p-value $<0.001$ and OR $(95 \%$ CI $)$ of $62(7.44-1359,19)$. The analysis of the relationship between maternal age and the developmental status of children showed a significant relationship with the p-value of 0.001 and OR $(95 \% \mathrm{CI})$ of 6.40 (1.96-20.90).

Table 4: The relationship of the marriage age of the mother and the age of giving birth by the mother with child development

\begin{tabular}{|c|c|c|c|}
\hline \multicolumn{4}{|c|}{ Age of married mother } \\
\hline & $\leq 18$ years & $>18$ years & $\mathbf{p}$ \\
\hline \multicolumn{4}{|c|}{ Child development } \\
\hline Delay & $30(71.4 \%)$ & 0 & \multirow{2}{*}{$<0.001$} \\
\hline Normal & $12(28.6 \%)$ & $25(100.0 \%)$ & \\
\hline OR $(95 \% \mathrm{CI})$ & \multicolumn{3}{|c|}{$62(7.44-1,359.19)$} \\
\hline \multicolumn{4}{|c|}{ Age of delivery mother } \\
\hline \multicolumn{4}{|c|}{ Child development } \\
\hline Delay & $15(75.0 \%)$ & $15(31.9 \%)$ & \multirow{2}{*}{0.001} \\
\hline Normal & $5(25.0 \%)$ & $5(25.0 \%)$ & \\
\hline OR $(95 \% \mathrm{CI})$ & \multicolumn{3}{|c|}{$6.40(1.96-20.90)$} \\
\hline
\end{tabular}




\section{DISCUSSION}

Of the 67 children, the married mothers had an average age of 18.51 years (SD 5.17 years) and the average marriage age of the father was 23.21 years (SD 5.50 years). This is in accordance with the study by Khaerul Umam that in couples who are married at an early age, the husband is often older than the wife. ${ }^{17}$ Establishment and economic security are one of the reasons for choosing to marry young to a more mature man but on the other hand it increases the risk of domestic violence which is experienced by young wives by an authoritarian husband. ${ }^{18}$

Many factors lie behind the occurrence of early marriage, among which are low education, low economic, customs and culture. ${ }^{19-22}$ the literature reveals gaps in the empirical evidence on the link between child marriage and the dropout of girls from school. This study identifies the 'tip-ping point' school grades in Nepal when the risk of dropout due to marriage is highest, mea-sures the effect of child marriage on girls' school dropout rates, and assesses associated risk factors. Weighted percentages were calculated to examine the grades at highest risk and the distribution of reasons for discontinuing school. Using the Nepal Multiple Indicator Cluster Survey (MICS In this research, most mothers' and fathers' education was primary school graduation (55.2\%) with most fathers working as farmers $(43.3 \%)$ and all the mothers not working, but housewives $(100 \%)$. From this research, most children are taken care of by their own mother $(74.6 \%)$ and the rest of the children are taken care of by the mother and other family members $(25.4 \%)$. In this study it appears that in this study the majority of mothers were married at an early age (62.7\%) but the age of giving birth was more than age 18 (70.1\%). This shows that not always mothers who marry at an early age will give birth at an early age as well.

The characteristics of education show a large role in the occurrence of early marriage. Education plays a role in delaying early marriage. ${ }^{23}$ This study found a significant relationship between early marriage age and a low maternal and paternal education level and the father's work. In this study, most children under five years old have the appropriate nutrition either at the age of marriage or age of delivery. Analysis of the relationship between marriage age/early childbirth and the growth (nutritional status) of children gave results that are not meaningful in the sense that early marriage and early childbirth do not cause growth disorders (nutritional status) of children. This is likely due to high public awareness of the nutritional status of children and the role of cadres and health workers, as well as the presence of other family members who participate in the role of childcare.

In this study, all mothers were housewives so they have plenty of time to take care of their children and to take them for a child growth check at Posyandu. The mothers also entirely exclusively breastfeed their child. All of the under-five years children in this study had a Towards Health Card (KMS) and undergo regularly weighing at Posyandu. Immunization is done on schedule until the age of 9 months (measles). The role and participation of midwives and cadres and local government support is instrumental in this area of Situbondo in monitoring the nutritional status of children in this subdistrict.

Growth and development are the results of twofactor interaction. Internal factors consist of race/ethnic or national differences, family, age, gender, genetic disorders, and chromosomal abnormalities, and children born of a certain race. External/environmental factors that affect the growth and development of children include nutrition, stimulation, psychology, and socioeconomics. ${ }^{24}$ Stimulation of the environment is essential for child growth. Children who receive directional stimulation regularly will develop faster than children who do not receive stimulation. Stimulation also maximizes genetic potential which belongs to the child. ${ }^{25}$

In this study there was a significant relationship found between early maternal marriage and child development. The risk of a child experiencing developmental disorders after a mother marries early is 62 times compared to an early marriage. The father's education remains low as well as his employment and income so that probably he still cannot receive enough information about what is the meaning of development and how to optimize his children's progress and stimulate optimal developmental aspects which the child needs.

\section{CONCLUSION}

Early marriage does not cause childhood developmental disorders, but early childhood marriage causes child developmental delays. On the other hand, early childbirth causes general developmental delays 
in children. Early marriage and early childbirth result in an increased risk of children experiencing stunted growth and developmental delays so it is necessary to perform screening and monitoring of child growth and development on a regular basis. How early marriage and early childbirth age affect a child's development should be used as a consideration in the current policy. Providing information to the public about the impact of early marriage on the growth of children can be used to promote public awareness on this issue.

Conflict of Interest: Authors declared that we have no conflict of interest.

\section{Acknowledgement: None}

\section{Source of Funding: NA}

Ethical Clearance: NA

\section{INTRODUCTION}

1. Jalal, F. Paparan Kepala BKKBN Pada Konferensi Pers Rakernas Program Kependudukan dan Keluarga Berencana Tahun 2014. (2014).

2. Utomo, A. J., Reimondos, A., Utomo, I. D., McDonald, P. F. \& Hull, T. H. Transition into marriage in Greater Jakarta. South East Asia Res. 24, 492-509 (2016).

3. Yunitasari, E., Pradanie, R. \& Susilawati, A. Early Marriage Based on Transcultural Nursing Theory in Kara Village Sampang. J. Ners 11, 164-169 (2016).

4. Aditya Budiman. UNICEF Minta Indonesia Hapus Pernikahan Usia Anak - Nasional Tempo.co. (2017). Available at: https://nasional.tempo.co/read/850685/ unicef-minta-indonesia-hapus-pernikahan-usiaanak. (Accessed: 28th February 2018)

5. Albasit, A. Jumlah Pernikahan Dini Indonesia Terbanyak Kedua di ASEAN. 2013, (2013).

6. BPS et al. Indonesia Demographic and Health Survey 2012. (BPS, BKKBN, Kemenkes, and ICF International, 2013).

7. Government of Indonesia. Undang-undang Republik Indonesia Nomor 1 Tahun 1974 Tentang Perkawinan. 1 (1974).

8. Yakubu, I. \& Salisu, W. J. Determinants of adolescent pregnancy in sub-Saharan Africa: a systematic review. Reprod. Health 15, 15 (2018).
9. Efevbera, Y., Bhabha, J., Farmer, P. E. \& Fink, G. Girl child marriage as a risk factor for early childhood development and stunting. Soc. Sci. Med. 185, 91-101 (2017).

10. Rumaseuw, R. et al. Factors Affecting Husband Participation in Antenatal Care Attendance and Delivery. doi:10.1088/1755-1315/116/1/012012

11. Efendi, F., Chen, C.-M., Kurniati, A. \& Berliana, S. M. Determinants of utilization of antenatal care services among adolescent girls and young women in Indonesia. Women Health 57, 614-629 (2017).

12. Kurniati, A., Chen, C.-M. M. C.-M., Efendi, F., Elizabeth Ku, L.-J. J. \& Berliana, S. M. M. S. M. Suami SIAGA: male engagement in maternal health in Indonesia. Heal. Policy Plan 32, 1203 1211 (2017).

13. Kurniati, A., Chen, C.-M., Efendi, F. \& Berliana, S. M. Factors influencing Indonesian women's use of maternal health care services. Health Care Women Int. 1-16 (2017). doi:10.1080/07399332.2 017.1393077

14. Utomo, I. \& Utomo, A. Indicators and Correlates of Adolescent Pregnancy in Indonesia: Results from 2010 Population Census and 2012 Indonesian Demographic and Health Survey. (UNFPA, 2013).

15. Nur, A. W. I. et al. Analysis of the Survival of Children Under Five in Indonesia and Associated Factors. doi:10.1088/1755-1315/116/1/012014

16. Berliana, S. M., Utami, E. D., Efendi, F. \& Kurniati, A. Premarital Sex Initiation and Time Interval to First Marriage Among Indonesians. Bull. Indones. Econ. Stud. 0, 1-27 (2018).

17. Noer, K. U. Angka Kematian Bayi Dan Persoalan Kesehatan Ibu Hamil Dalam Budaya Madura. (2010). Available at: https://archive.org/stream/ AkbDanKesehatanReproduksiDiMadura/ AkbDanKesproDiMadura_djvu.txt.

18. UNICEF. Early Marriage A Harmful Traditional Practice A Statistical Exploration 2005. (UNICEF, 2005).

19. Sekine, K. \& Hodgkin, M. E. Effect of child marriage on girls' school dropout in Nepal: Analysis of data from the Multiple Indicator 
198 Indian Journal of Public Health Research \& Development, September 2018, Vol.9, No. 9

Cluster Survey 2014. 1-13 (2017). doi:10.1371/ journal.pone. 0180176

20. Gurmu, E. \& Dejene, T. Trends and differentials of adolescent motherhood in Ethiopia: evidences from 2005 Demographic and Health Survey. Afr J Reprod Heal. 16, 162-174 (2012).

21. Kamal, S. M. M. \& Hassan, C. H. Child marriage and its association with adverse reproductive outcomes for women in Bangladesh. Asia Pacific J. Public Heal. 27, NP1492-NP1506 (2015).

22. Mishbahatul, E., Has, M., Syaltut, M., Kusumaningrum, T. \& Efendi, F. Early weaning food for infants (0-6 months old) in madurese people based on transcultural nursing theory. doi:10.1088/1755-1315/116/1/012059

23. Fadlyana, E. \& Larasaty, S. Pernikahan Usia Dini dan Permasalahannya. Sari Pediatr. 11, 136-141 (2016).

24. Narendra, M. B. Penilaian pertumbuhan dan perkembangan anak. Jakarta EGC (2003).

25. Soetjiningsih. Tumbuh Kembang Remaja dan Permasalahannya. Sagung Seto. Jakarta 320, (2004). 